\title{
Transition to Digital Distribution Platforms and Business Model Evolution
}

\author{
William W. Baber \\ Kyoto University \\ baber@gsm.kyoto-u.ac.jp
}

\author{
Arto Ojala \\ University of Jyväskylä \\ arto.k.ojala@jyu.fi
}

\author{
Ricardo Martinez \\ Kyoto University \\ martinez.ricardo.32n@kyoto-u.jp
}

\begin{abstract}
How do business models evolve when technology-based firms move from physical distribution channels to digital distribution platforms? This is an important question, since digitalization of distribution platforms provides new opportunities to expand the reach and customer base of technology-based firms. Based on an in-depth multi-case study of four Japanese high-tech firms, we seek to expand our understanding of digital transformation and business model literature. Our findings indicate that that through digital transformation, the case firms' business models evolved toward more constant interaction with the market, in particular through digital platforms. This interaction includes growing and leveraging network partners, reducing both intermediate actors and supplier dependence, and improving the information flow to and from end users.
\end{abstract}

\section{Introduction}

Digitalization of distribution platforms provides new opportunities for firms developing such platforms $[1,2]$ and firms delivering and multihoming their digital services and content through these platforms to endusers [3]. Digital innovations, like new distribution platforms ${ }^{1}$, also change business models [4] as firms have to adapt their business to a new environment. However, as digitalization of delivery channels and its impact on firms' business models represent relatively new phenomena, we know quite little about how business models of high-tech firms evolve over time when they adapt new technologies and adjust their business models to the new environment.

In general, business model evolution has been studied through resource re-combination [e.g. 5, 6] and entrepreneurial actions where entrepreneurs create and discover new opportunities [4]. In addition to creating or discovering opportunities, firms may adjust their platforms for distributing products, marshalling partners, gaining information, and gathering resources. While the cost reduction advantages of moving to new

1 In this study, we use the term "digital distribution platform" to refer platforms that content providers can use to support the transfer of the focal firm's products to endusers. Examples of platforms that are germane to digital content firms include Google Play, App Store, Steam, PlayStation Store, Spotify, Netflix, etc. platforms are well documented [7, 8], empirical evidence from this study suggests that firms may realize other benefits that are important for success in increasingly competitive environments.

The main research question asked by this paper is "How do business models evolve when technologybased firms transition from physical distribution channels to digital distribution platforms?" In order to provide an answer to the research question, we conducted a multi case study with four high-technology ${ }^{2}$ firms by investigating the evolution of their business models when they transitioned from physical distribution channels to digital distribution platforms.

\section{Theoretical framework}

In this chapter, we first talk about business models and business model evolution. Thereafter, we present five different elements of business models that we use to study change and evolution of business models. In the end, we discuss platforms, distribution platforms, and the concept of multihoming.

\subsection{Business models}

Business models - how firms create, capture, and deliver value- have been of scholarly interest for decades. The literature on business models has greatly contributed to our knowledge of basic elements and characteristics of business models $[9,10,11,12,13]$, business models in information systems $[14,15,16]$, business models in a firms' global expansion [17, 18], and evolution of business models [4, 6, 19, 20, 21], among other topics. Overall, we have an extensive amount of literature on business models [13] and their adaption in practice [22].

Digital products and related ecosystems commonly evolve unpredictably making firms' business models less stable and constantly changing [4, 23]. Hence, firms' success becomes closely reliant on their capabilities to configure resources $[24,25]$ and effectuate changes in a firm business model that is, in many cases, path dependent [19] and subject to possibilities and boundaries set by existing technologies [4].

2 In this study, we define technology-based firms as firms making extensive use of information technology as their main input resource in order to produce the desired value to be delivered to the customers. 
When we take a closer look, the existing literature describes the concept of a business model in various ways. On a general level, business models can be seen as depictions of "stories that explain how enterprises work" [26]. Further, a business model represents interdependent activities above and beyond the focal firm that allows the firm to create value with its partners [12] describing how a firm and its partners create, market, and deliver that value to gain and sustain revenue [10].

\subsection{Different elements of business model}

Given the flexibility and inaccuracy of the concept of business model, it is necessary for researchers to define its key elements matching the purpose of their study [27]. For this reason, we apply roughly the four business model elements introduced by Ojala [4] which are largely based on the business model pillars by Osterwalder et al. [10]. However, we integrate a fifth element, information flow, into the model. Based on previous studies [28, 29], it plays an important role in binding other elements of the business model together. It also shows explicitly the changes that occur in firms' information exchange among the different business model elements. Accordingly, the key business model elements used in this study are illustrated in Figure 1 and explained below.

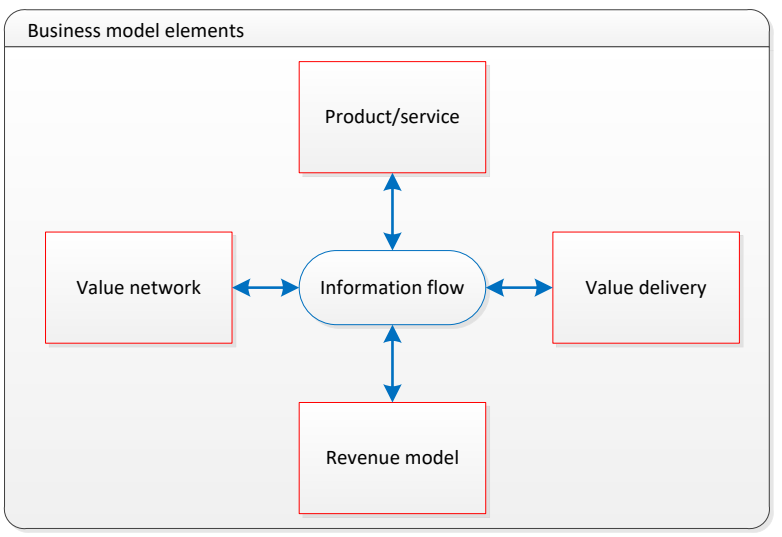

Fig. 1. Key business model elements used in this study.

The first element, product and/or service, refers to a firm's product/service that it develops and markets, and the business logic behind it. This element explains how the product or service is related to other technologies in the market $[30,31]$ and how it provides value for the external partners, stakeholders, customers, etc. included in the model $[10,22,32,33,34]$.

Value network, the second element, refers to the key actors within the ecosystem where the firm operates [35, $36,37]$. In order to operate successfully in a value network, a firm needs to identify the value of its offering to other actors within the ecosystem. Further, it is important to consider how the value can be delivered so that it benefits all the actors in the network [34, 38].
After that, it is possible to see how the other actors could add value to the firm's own offering. That is, partners within the ecosystem may provide different kinds of technologies, access to the interfaces and components, etc. enabling or supporting its activities in the market [30].

The third element, value delivery, covers how value is delivered to the various partners and customers in the ecosystem [4]. For instance, new technologies enable firms to create and adapt new and faster channels to deliver value and access to new market segments [39]. This aspect is close to networking as it should describe how a firm gets in contact with other actors within their ecosystem $[10,22]$ and how value is exchanged with the firm's customers and partners [11, 22, 32].

The fourth element, revenue model, includes the process how a firm makes money through its actions in the market. In other words, this element explains how the value that a firm offers to its customers, partners, or other actors within the ecosystem, can generate financial revenue [4]. Revenue model has a central role in several works related to business models [10, 11, 13, 22, 40].

The last element, information flow, refers to the movement of intangible value packaged as information regardless of the route by which it travels among the partners and customers within the business model [28]. This information flow not only includes pushing of information from the focal firm towards its partners or customers, but also information that it receives from them and that it uses in a meaningful way to create value or to reassess the business model itself $[28,33]$. This element acts as a link among all the business model elements [28, 29] allowing a firm to exchange information that is valuable to the network.

\subsection{Platforms}

Platforms have been defined as interconnected systems comprised of a core and modules [41]. Of interest to this paper are platforms that relate to digital products and services and which are used by many actors [41]. Digital platforms can be defined as extensible codebases where third parties add complementarities in the form of new modules and services [36, 42].

Interaction between different actors has an important role in Bresnahan and Greenstein's [43] definition of platforms as bundles of standardized elements that provide a framework for buyers and sellers to coordinate and covers physical platforms as well as digital ones. Neither party will be interested if both parties are not [44]. Regardless of physical or digital footprint, platforms are systems that enable two or multi-sided markets to interact [44]. Physical platforms have noncore features similar to digital platforms such as blocking users and shaping the behavior of partners [45]. This paper is mainly concerned with digital platforms that companies, users, and intermediaries coordinate around. However, physical platforms also 
play a role in understanding how software business models evolve through digital transformation.

Loosely coupled multilayered architecture of digital platforms [57] with standard interfaces enables firms to develop their content for different platforms that can be used to bring content available to different devices [1, 57]. Digital distribution platforms $[55,56]$ have a critical role to firms providing content and related services for different platform. These platforms help content providers to reach a large number of potential customers easily and quickly [55, 56, 58]. Although firms operating platforms might have strict control regarding which devices the platform can be used (e.g. Apple controls and limits usage of its iOS platform only to Apple's products), content providers might seek to multihome their offering through several platforms. For example, videogame developers $[1,58]$ or firms operating in the music industry [59] might look for several alternative platforms to multihome their content. That is, when multiple platforms can be used to carry the same content, multihoming has an important role to extend content providers' distribution possibilities [46]. A firm might offer the content on multiple platforms and customers can use more than one device or network to access the same platform service [37]. As a result, content can be offered across multiple platforms, and the same platform can be used to distribute and offer content from other content providers [46, 47].

Platforms also connect different actors in an ecosystem [37]. For example, when a video game is bought with a credit card, the payment platform brings together retailer and consumer while the gamer plays on another platform such as a console. Similarly, video game developers may place a game on multiple platforms such as an App store and Steam for PC environment, gaining additional markets through multihoming [48]. Thus, multihoming brings advantages to all sides of the market that the platform appeals to, for example, gamers, game publishers, advertisers, and payment systems.

\section{Research method}

The research method guiding this study had to be suitable for understanding complex social phenomenon while providing an in-depth description of it in the context of a real-life environment over which the investigator has little or no control. According to these criteria, a qualitative multi-case study was selected [49]. Instead of relying on a single-case study, multiple case studies were selected not only to add general confidence to the findings but also as a way to gain deeper understanding and explanation of the observed phenomenon, since multiple instances of study help to understand how the specific conditions of each case findings may be related [50].

The selected firms were chosen according to the following criteria: (i) The firms were relatively small (from 5 to 150 employees) which helped to form better understanding of the business model and to access the key decision makers, (ii) the sample firms included both relatively new and old companies according to their date of establishment, (iii) the firms used several platforms to deliver product(s) and related services, (iv) at least one representative from the strategic-level management of the firm was accessible to the researcher in order to facilitate access to key staff and information resources in the course of the interviews [51]. Actual selection was done by convenience sampling based on the first and second-degree networks of the authors. A general guideline in the selection criteria was to create a sample that exhibited diverse characteristics including polar type operating contexts for a better understanding of the possible links of these different contexts [52]. An overview of the selected firms can be seen in Table 1 . All the case firms were from Japan, one of the leading countries in digital transformation [60].

\section{Table 1. Overview of the selected firms}

\begin{tabular}{|l|l|l|l|}
\hline Firm & $\begin{array}{l}\text { Year of } \\
\text { establishment }\end{array}$ & $\begin{array}{l}\text { Main } \\
\text { activity }\end{array}$ & $\begin{array}{l}\text { Headquarters } \\
\text { location }\end{array}$ \\
\hline A & 1984 & $\begin{array}{l}\text { Specialized } \\
\text { software } \\
\text { development }\end{array}$ & Kyoto, Japan \\
\hline B & 1990 & $\begin{array}{l}\text { Videogame } \\
\text { development }\end{array}$ & Kyoto, Japan \\
\hline C & 2001 & $\begin{array}{l}\text { Videogame } \\
\text { development }\end{array}$ & Kyoto, Japan \\
\hline D & 2006 & $\begin{array}{l}\text { Videogame } \\
\text { development }\end{array}$ & Tokyo, Japan \\
\hline
\end{tabular}

\subsection{Data collection}

For the purpose of data collection, interviews were conducted to gather qualitative data from expert sources. This study chose qualitative data in order to understand the transition to digital distribution platforms and the evolution of the business model over time and the nature of such changes. Accordingly, the interview included mostly open questions inviting interviewees to recall past experiences. A set of guiding questions opened discussions, but interview participants were informed that flexibility was appropriate and even necessary in the study. Semi-structured interviews were held, covering the following aspects: (i) The origins of the firm's distribution model and development of initial business model, (ii) changes made in the firm's distribution and business model as a reaction to new technologies or competition, (iii) confirmation of the current distribution and business model, and (iv) views on the envisioned future of the firm. While this study focuses on the changes made to the business model throughout the firm's history, other topics provided essential context in which to understand the data. 
While the questions covered common material, they were tailored to each case firm based on data from publicly available sources, such as websites. This data contained basic information about establishment, size, business activity, products, and important events in the firm's history. Basing the interview questions on this information provided a way to frame the conversation such that the firm was explored appropriately without missing important material. This approach was also tool for the time management of the interview since access to the informants was limited to one or two hours per session.

Interviews were held mostly in the case firms' headquarters, but also in more informal settings such as cafes or university offices. The interviews were conducted in English. Employees of the case firms helped to overcome a potential language barrier by translating comments made in Japanese by their colleagues. In the case of Firm D, a translator was hired for the session. During the interview sessions, all interview notes were in English; these were scanned and evaluated by the researchers.

The interviews were recorded and transcribed. Additional secondary information was gathered from firm brochures, news articles, and books. Further, news articles and old advertising material from earlier stages of the companies were collected and used to confirm the consistency of the primary data in order to reduce retrospective bias [51]. Comparing this secondary information to the primary interview data made it possible to confirm the information and triangulate [50]. Thereafter, representations of the business models were drafted as value network diagrams (see example in Ojala and Tyrväinen [61]). In some instances, a Business Model Canvas was drafted and used to build diagrams.

Follow-up interviews were conducted in order to confirm the data from the initial interview. Relevant data for confirmation such as value network diagrams, interview transcripts were shared with the representatives in the follow-up interviews. They confirmed or helped modify the information presented by the researchers. In follow-up interviews, specific questions were clarified and questions missed in the initial interview were asked. Additional follow-up and confirmation of information was conducted by email.
Table 2. List of interviews conducted

\begin{tabular}{|l|l|l|l|}
\hline Firm & Date & Length & $\begin{array}{l}\text { Role of the } \\
\text { interviewee(s) }\end{array}$ \\
\hline A & May 29, 2017 & $\begin{array}{l}1.5 \\
\text { hours }\end{array}$ & President \\
\cline { 2 - 4 } & Oct 10, 2017 & $\begin{array}{l}1.5 \\
\text { hours }\end{array}$ & President \\
\hline \multirow{2}{*}{ B } & June 16, 2017 & 2 hours & $\begin{array}{l}\text { CFO } \\
\text { Publishing producer }\end{array}$ \\
\cline { 2 - 4 } & $\begin{array}{l}\text { September 16, } \\
2017\end{array}$ & 1 hour & Publishing producer \\
\hline C & \begin{tabular}{l} 
August 9, 2017 \\
\cline { 2 - 5 }
\end{tabular} & $\begin{array}{l}\text { September 19, hours } \\
2017\end{array}$ & $\begin{array}{l}\text { Senior Producer } \\
\text { Creative Producer }\end{array}$ \\
\hline D & $\begin{array}{l}\text { November } \\
2017\end{array}$ & $\begin{array}{l}1.5 \\
\text { hours }\end{array}$ & President \\
\hline
\end{tabular}

\subsection{Data analysis}

The method of data analysis was composed of three concurrent flows of activity, as recommended by Miles et al. [50]: (i) data condensation, (ii) data display and (iii) drawing and verifying conclusions. In data condensation, the collected data from both primary and secondary sources of information was made concise for more manageable analysis. The interview transcripts provided the basis of chronological case narratives. Secondary sources enriched the narratives and verified data such as dates. In the data display activity condensed data was transformed into tables and figures. In particular, graphic representations of the business models of relevant stage of the case firm were built. In some instances, a business model canvas was used as an intermediate step. During drawing and verifying conclusions, all relevant "patterns, explanations, causal flow and propositions" [50] were noted. This activity was not done once to draw final conclusions. Rather, early conclusions were drawn and subsequently discarded, transformed or confirmed during the course of analysis. Moreover, conclusions regarding case firms were confirmed in follow-up interviews or email by the informants.

\section{Research findings}

In this section we present the case narratives of each case firm. We aim to demonstrate how their business model changed as they transitioned their content to new distribution platforms. 


\subsection{Firm A}

Firm A started operations in 1984. An opportunity was discovered by the president: a product that could manipulate Japanese ideograms, or kanji, and which was acquired by Firm A, brought to Japan, customized, localized and released to become a success. The president attributes the success partly to timing, "...the market was so immature at the time... It was still a completely wide-open market". This success made it possible to strike deals with publishers, an association of national universities in Japan and then forge relationships with key academics in order to complete the initial business model.

A second software package was developed using the previously gained knowledge and an acquired word processor. It was also a success leading to a packaged software business model. Firm A then acquired a font company as well as font sets from different firms and engineered them to handle East-European and Asian languages. The resulting font library was licensed to major vendors such as game makers and vendors of embedded systems and distributed physically. Awareness of the industry environment led the president of Firm A to make this move.

Around the year 2000, as internet technology increasingly allowed online software distribution, Firm A offered software updates online and stopped shipping physical media discs whenever possible, leading to an adjustment of the business model that decreased costs. Nonetheless, some customers require physical products, USB drives or CDs, and can receive these by post. The internet also allowed Firm A to connect efficiently with new outsourcing partners in China and leave behind predominantly face to face contracting with local university students. Another benefit has been accessing to Amazon back office services which allow greater operating efficiency.

As the Apple App Store gained acceptance in 2009, Firm A began to use this platform as well. However, the sales volume did not make up for the $30 \%$ commission fee and the firm uses the platform only for free products which raise their profile. Firm A now offers most of its software products directly through its own website coming to an optimized, multihoming business model that allows efficient use of competing platforms. Despite constantly reassessing the markets and platforms by maintaining what the president calls a "helicopter view", Firm A has not radically changed its licensing and package business models since moving to digital platforms.

\subsection{Firm B}

Firm B started operations in 1990 on the desire of the founder to create video games. With no previous experience in the videogame industry, the founder recruited a team that developed games for consoles.
Firm B had little negotiation power with retailers, who would accept packaged games physically from Firm B, returning any unsold product with no data about end users. Generally, contact with end users was minimal, especially as online communities were not common. The time, hardware, and software requirements to develop games for consoles were high and therefore this simple business model remained risky.

Amidst the difficulties of the console game business, the CEO decided in 2001 to radically refocus its business to develop games for feature phones. At this time such devices were increasingly common and people were using them not only for telephony, but also for games. By recognizing and entering the feature phone game business, Firm B registered a sharp decrease in development costs, since the technology required became simpler and less costly while the game complexity also decreased. Development time fell from around one year to a couple months. Revenue came from mobile operators who took $30 \%$ of the payments made by end users, who were charged monthly in a subscription-based phone bill. New sales and ranking data became available to the firm through this change of platform, impacting the business model in terms of logic, structure, revenue, and expanded information flow from users and carriers.

In 2009, when the iPhone and other smart devices were gaining popularity among consumers, the CEO and a top director completely refocused the business again, this time cutting the previous platform and targeting game development for smartphones. This move meant easier access to a broader population of customers through online distribution platforms such as Apple App Store and Google Play Store. One game became particularly successful, allowing Firm B to gather a customer base who they could now reach directly through social media tools in order to gain feedback information faster. The main development costs were now not technology but the specialized human talent in the firm. The subscription model changed to a free-toplay model including optional in game purchase of digital add-ons to enhance the experience. Most of the revenue now comes from advertisers, a newly accessed partner, that pay to have ads displayed to the end users. The elements of the business model evolved further, though with less radical change to the business model than the transition from the physical to the first digital distribution platform. The current business model uses multiple digital platforms, providing additional flows of information and access to customers. Currently, Firm B continues to assess business opportunities in emerging technologies, such as Virtual Reality games, led by an internal team rather than relying on the CEO or other top manager as the firm had previously. 


\subsection{Firm C}

Firm C started operations in 2001. The founder's motivation was to create original games based on his previous work as a developer for a major videogame company. As a new firm with limited resources, it was necessary to first create a business model as an outsourcer to large established firms based on technical expertise just as consoles were improving to allow greater graphic capabilities. During this period, Firm $\mathrm{C}$ accumulated experience and talented individuals within the firm in addition to developing business relationships with established videogame companies and console manufacturers. The founder's long-term strategy was to develop expertise and then overhaul the firm to create complete games.

As console manufacturers set up distribution platforms and Firm $\mathrm{C}$ developed its own games, they transitioned from physical distribution to corporate clients to digital distribution via Internet connection to end users. With reduced marketing expenses, Firm $\mathrm{C}$ was able to release game titles as a developer and as a publisher; in this model a $30 \%$ share of the revenues went to the distribution platform owner. As social media platforms improved, they brought user information to the firm with increasing ease, “...it's about maybe 2003, or 2004 when those social media really started to catch on."

Firm C then, in 2012, organized an independent game event because they had found no meaningful participation in major industry trade events. Sponsoring such events increased Firm C's exposure and created physical networks with other independent game creators and users, adding new information flows into its business model. The results have meant incremental improvement in game development and business operations.

Firm C has kept focus on game development for consoles, but also released games for the PC in 2012 and 2014 through third party online PC-based distribution platforms and through self-publishing. Multihoming on Steam, consoles, and other platforms has allowed Firm $\mathrm{C}$ to reach new markets and build brand recognition. Thus, its business model has expanded and evolved to mimic its network of partners and information sources and include publishing as well as outsourcing. These distribution platforms, have delivered more technical user data than were available through social media. Currently, Firm $\mathrm{C}$ is working together with local government entities to develop games promoting areas of interest such as tourism.

\subsection{Firm D}

Firm D was established in 2006. With experience in a well-established videogame company, the founder and CEO of Firm D started the firm to develop games with more innovative and creative ideas than possible at the previous employer. Limited by initial capital and without existing reputation, getting customers proved to be difficult, thus the initial business model was to solicit tasks from other videogame companies, as an outsourcer.

Some two years later, Firm D secured a contract with a well-established domestic videogame company facing development delays due to lack of personnel from another contractor. The resulting hit game in 2009 boosted Firm D's reputation and led to a contract with a foreign company and another successful game. Thereafter Firm D received a strategic development role from a major console and videogame maker. At this point, Firm D conserved part of the revenue streams to fund its own original game which appeared in 2012 on Xbox. Avoiding debt and therefore loss of decisionmaking, Firm D drastically expanded from an outsourcing business model to create original games, however in partnership with a publisher who bore marketing expenses in exchange for a share of revenue. Reassessing the quality of Software Developer Kits from major industry partners led the founder of Firm D to the strategic decision to develop advanced technical skills in house that allow higher quality work output. With an original game success and new digital publishing platforms such as App Store and Android in 2013 and Play Station in 2014, Firm D's business model could evolve to include developing and publishing games while reaching more end users, partner companies, and freelance workers. The movement of information from users has become more direct and useful because it no longer comes solely through clients who order outsourcing work. Despite the exploitation of platforms for their own game publishing, Firm D has increased contract work for other videogame companies.

The specific effects on the case firms' business model elements when they transitioned from physical distribution channels to the digital distribution platforms are elaborated in Table 3. 
Table 3. Effects of adoption digital distribution platform(s) on case firms' business model

\begin{tabular}{|c|c|c|c|c|}
\hline & Firm A & Firm B & Firm C & Firm D \\
\hline Product/service & $\begin{array}{l}\text {-Creation of } \\
\text { free products } \\
\text {-Products } \\
\text { released } \\
\text { through App } \\
\text { Store for brand } \\
\text { building, not } \\
\text { revenue }\end{array}$ & $\begin{array}{l}\text {-Increased and } \\
\text { removed } \\
\text { products } \\
\text { radically with } \\
\text { new platforms } \\
\text {-Decreased } \\
\text { development } \\
\text { time } \\
\text {-Multihoming of } \\
\text { products }\end{array}$ & $\begin{array}{l}\text {-Created new } \\
\text { products (games) } \\
\text {-Multihoming of } \\
\text { products }\end{array}$ & $\begin{array}{l}\text {-Created new } \\
\text { products (games) } \\
\text {-Multihoming of } \\
\text { products }\end{array}$ \\
\hline Value network & $\begin{array}{l}\text {-Included App } \\
\text { Store to raise } \\
\text { awareness }\end{array}$ & $\begin{array}{l}\text {-Abandoned } \\
\text { physical } \\
\text { distribution } \\
\text {-Included new } \\
\text { suppliers and } \\
\text { revenue sources } \\
\text {-Brought new } \\
\text { parties in } \\
\text {-Reached new } \\
\text { segments }\end{array}$ & $\begin{array}{l}\text {-Abandoned major } \\
\text { trade shows } \\
\text {-Included mass } \\
\text { market users } \\
\text {-Brought new } \\
\text { parties in }\end{array}$ & $\begin{array}{l}\text {-Brought new } \\
\text { parties in } \\
\text {-Included mass } \\
\text { market users } \\
\text {-Moved key } \\
\text { technology in- } \\
\text { house, away from } \\
\text { suppliers }\end{array}$ \\
\hline Value delivery & $\begin{array}{l}\text {-Abandoned } \\
\text { most physical } \\
\text { distribution } \\
\text {-Faster } \\
\text { delivery }\end{array}$ & $\begin{array}{l}\text {-Faster to market } \\
\text {-Multihomed } \\
\text { online } \\
\text { distribution }\end{array}$ & $\begin{array}{l}\text {-Physical } \\
\text { enhanced with e- } \\
\text { communication } \\
\text {-Multihomed } \\
\text { online distribution }\end{array}$ & $\begin{array}{l}\text {-Physical } \\
\text { enhanced with e- } \\
\text { communication } \\
\text {-Multihomed } \\
\text { online distribution }\end{array}$ \\
\hline Revenue model & $\begin{array}{l}\text {-Abandoned } \\
\text { most } \\
\text { distribution } \\
\text { costs } \\
\text {-Avoided App } \\
\text { Store } \\
\text {-Reduced back } \\
\text { office costs }\end{array}$ & $\begin{array}{l}\text {-Included } \\
\text { advertisers, in- } \\
\text { app payments } \\
\text {-Faster, more } \\
\text { direct payments }\end{array}$ & $\begin{array}{l}\text {-Accessed new } \\
\text { customers } \\
\text {-Direct sales and } \\
\text { in-app purchases }\end{array}$ & $\begin{array}{l}\text {-Accessed new } \\
\text { customers } \\
\text {-In-app purchases }\end{array}$ \\
\hline Information flow & $\begin{array}{l}\text {-Gained faster } \\
\text { responses from } \\
\text { customers }\end{array}$ & $\begin{array}{l}\text {-Evolved from } \\
\text { minimal and } \\
\text { manual to high } \\
\text { detail, faster, and } \\
\text { automated } \\
\text {-Direct from } \\
\text { users and via } \\
\text { multiple } \\
\text { platforms }\end{array}$ & $\begin{array}{l}\text {-Direct from users } \\
\text { and via multiple } \\
\text { platforms } \\
\text {-Developed } \\
\text { physical } \\
\text { interaction with } \\
\text { users }\end{array}$ & $\begin{array}{l}\text {-Direct from users } \\
\text { and via multiple } \\
\text { platforms }\end{array}$ \\
\hline
\end{tabular}

\section{Discussion}

Based on the case findings, we can now answer to our research question set in the introduction: How do business models evolve when technology-based firms transition from physical distribution channels to digital distribution platforms? Applying the business model framework of Ojala [4] plus the element of information flow, we can see that there were several important changes in the all elements of the business models. Below we discuss the main changes observed in the different elements of the business model

Change in the product and service element enabled firms to bring completely new products to market and abandon existing ones as content distribution changed 
from physical channels to digital distribution platforms. These digital platforms enable also multihoming and the resulting modification of products for new platforms allows access to new market segments [cf. 37]. The transition to digital platforms can also mean radically faster development cycles and time to market improvements, especially if a distribution platform supports less demanding software, for example mobile phones compared to gaming consoles. Product change does not always mean creation of a hit product, however the capacity to change and create products means long term survival through accessing a platform or multihoming on multiple platforms.

Value networks change as some old network members are abandoned and new ones added while the network generally becomes more complex over time. This evidence is in line with previous works on business models $[4,20]$ and value networks [34]. However, the findings also extend these works by revealing that the most radical changes appear to come with the first moves to digital platforms. These radical simplifying changes appear more strongly on the supply side of the value network whereas changes on the downstream delivery side tend toward greater complexity with new platforms and multihoming.

Changes in value delivery give rise to radical changes in speed of product delivery and product development mainly due to digitalization of delivery network and partly due to simplification of the supply chain. This is consistent with the findings of Rayna and Striukova [39], expanding their findings on 3D technologies to more general high-technology markets. Interestingly, some of the case firms were also able to gain benefits of face to face interactions with ecommunication tools in order to increase responsivity to clients and knowledge about them. This highlights the important role of platforms as a communication tool improving the flow of information.

Revenue models change drastically with digitalization providing access to new payers such as advertisers and new market segments. Additionally, revenue structures of some games change from one time only purchases to frequent payments through in-app purchases and advertising based on frequency of display. Hence, transition to digital platforms expanded new opportunities radically to generate revenue. This extends pricing literature related to cloud computing toward pricing strategies of digital platforms [cf. 53, 54].

Information flow develops with platform digitalization in volume, granularity and format. Physical distribution meant a slow flow of limited information, in some cases retailers were in control of this flow and did not promote or develop it. Some digital platforms however allow movement of information from apps as well as from the platform. Thus, granularity can be adjusted by firms through the design of the app. Some information can be collected or refined at the user level thereby maximizing its value to the firm and minimizing processing time after collection. For instance, firms $\mathrm{C}$ and $\mathrm{D}$, which pursue original equipment manufacturing activities, were able to enhance their gathering of information through electronic communication and collaboration tools.

\section{Conclusions}

This qualitative case study makes notable contributions to the IS and business model literature. Firstly, the findings about fundamental concepts of business models represented in this study provide a clearer picture of the origin and evolution of changes to business models. Further, it demonstrates how high-technology firms' business models change when they transfer from physical distribution channels to digital distribution platforms. Although the change and evolution aspects of the business models $[4,6,19]$ have attracted increasing interest, to the best of our knowledge, this is first systematic study aiming to reveal how such change impacts the business model. Secondly, this paper contributes to our understanding of digitalization and how digital platforms bring advantages for content providers through multihoming, launching new products, extending revenue models, and improving information flow between actors in the value network.

The findings of this research have implications for managers of digital businesses. One implication is the importance of maintaining awareness of the overall business environment. Each of the case firms made successful strategic moves based on the broad knowledge and overview of a high-level individual and some have institutionalized this activity in larger groups of staff. Another implication is to actively search for new ways to gain customer access and information from them. The firms studied in this report all found new markets as technology and platforms changed, however they did so by intentional movement to new platforms. One implication that the researchers found somewhat surprising was the maintenance of face to face interaction. Firms can benefit by optimizing human interactions even with end users and did not transition to digital platforms for this aspect of information gathering. Additionally, managers may find that it is to their benefit, like the case study firms, to simplify the supply side of the value chain but boost the power and thereby the complexity of the delivery side of the value chain. Though managers may seek to avoid complexity, the findings suggest that complexity is appropriate in order to reach more customer segments and gain more insights about them and the products they use.

Overall, this study focused on digital transformation and its impact to a business model mainly from the content provider's perspective. Accordingly, the findings of this study are rather content specific and cannot be generalized to digital transitions in other contexts without further study. Although the case studies used for this study revealed several interesting insights, more work is required to acquire in-depth 
theoretical understanding of digital transformation. From the methodology point of view, longitudinal studies would help us to better understand the digital transformation as an evolutionary process.

\section{References}

[1] Ojala, A. \& Lyytinen, K. 2018. Competition Logics during Digital Platform Evolution. In Proceedings of the 51 st Hawaii International Conference on System Sciences (HICSS 2018), 1026-1035.

[2] Parker, G.G., Van Alstyne, M.W. \& Choudary, S.P. 2016. Platform Revolution: How Networked Markets Are Transforming the Economy - and How to Make Them Work for You. W. W. Norton \& Company.

[3] Belleflamme, P. \& Toulemond, E. 2016. Negative intragroup externalities in two-sided markets. International Economic Review, 50(1), 245-272.

[4] Ojala, A. 2016. Business models and opportunity creation: How IT entrepreneurs create and develop business models under uncertainty. Information Systems Journal, 26(5), 451476.

[5] Achtenhagen, L, Melin, L. \& Naldi, L. 2013. Dynamics of Business Models - Strategizing, Critical Capabilities and Activities for Sustained Value Creation. Long Range Planning, 46(6), 427-442.

[6] Demil, B. \& Lecocq, X. 2010. Business Model Evolution: In Search of Dynamic Consistency. Long Range Planning, 43(2), 227-246.

[7] Cortimiglia, M. N., Ghezzi, A., \& Renga, F. 2011. Mobile applications and their delivery platforms. IT Professional, 13(5), 51-56.

[8] Diba, V., \& Wagner, C. 2015. Success within app distribution platforms: The contribution of app diversity and app cohesivity. Proceedings of the Annual Hawaii International Conference on System Sciences, 4304-4313.

[9] Baden-Fuller, C. \& Morgan, M.S. 2010. Business Models as Models. Long Range Planning, 43(2), 156-171.

[10] Osterwalder, A., Pigneur, Y. \& Tucci, C. L. 2005. Clarifying Business Models: Origins, Present, and Future of the Concept. Communications of the Association for Information Systems, 15, 1-43.

[11] Teece, D. J. 2010. Business models, business strategy and innovation. Long Range Planning, 43(2-3), 172-194.

[12] Zott, C. \& Amit, R. 2010. Business model design: An activity system perspective. Long Range Planning, 43(2-3), 216-226.

[13] Zott, C., Amit, R. \& Massa, L. 2011. The Business Model: Recent Developments and Future Research. Journal of Management, 37(4), 1019-1042.

[14] Clemons, E.K. 2009. Business Models for Monetizing Internet Applications and Web Sites: Experience, Theory, and Predictions. Journal of Management Information Systems, 26(2), 15-41.
[15] Deodhar, S.J., Saxena, K.B.C., Gupta, R.K. \& Ruohonen, M. 2012. Strategies for software-based hybrid business models. The Journal of Strategic Information Systems, 21(4), 274-294.

[16] Osterwalder, A. \& Pigneur, Y. 2013. Designing Business Models and Similar Strategic Objects: The Contribution of IS. Journal of the Association for Information Systems, 14, 237 244.

[17] Khan, N. \& Fitzgera, G. 2004. Dimensions of Offshore Outsourcing Business Models. Journal of Information Technology Case and Application Research, 6(3), 35-50.

[18] Ojala, A., \& Tyrväinen, P. 2006. Business models and market entry mode choice of small software firms. Journal of International Entrepreneurship, 4(2-3), 69-81.

[19] Bohnsack, R., Pinkse, J. \& Kolk, A. 2014. Business models for sustainable technologies: Exploring business model evolution in the case of electric vehicles. Research Policy, 43(2), 284-300.

[20] Cavalcante, S., Kesting, P. \& Ulhoi, J. 2011. Business model dynamics and innovation:(re) establishing the missing linkages. Management decision, 49(8), 1327-1342.

[21] Saebi et al., 2017

[22] Osterwalder, A., \& Pigneur, Y. (2010). Business Model Generation: A Handbook for Visionaries, Game Changers, and Challengers. John Wiley \& Sons.

[23] Nambisan, S. 2017. "Digital Entrepreneurship: Toward a Digital Technology Perspective of Entrepreneurship," Entrepreneurship Theory and Practice (41:6), 1029-1055.

[24] Amit, R. \& Han, X. 2017. Value Creation through Novel Resource Configurations in a Digitally Enabled World. Strategic Entrepreneurship Journal, 11(3), 228-242.

[25] Simon, P. 2011. The age of the platform: How Amazon, Apple, Facebook, and Google Have Redefined Business, Las Vegas: Motion Publishing.

[26] Magretta, J. 2002. Why Business Models Matter. Harvard Business Review, 3-8.

[27] Luoma, E. 2013. Examining Business Models of Software-as-a-Service Companies. Jyväskylä studies in computing.

[28] Timmers, P. 1998. Business models for electronic markets. Electronic markets, 8(2), 3-8.

[29] Weill, P. \& Vitale, M. 2001. Place to space: Migrating to eBusiness Models. Harvard Business Press.

[30] Adomavicius, G., Bockstedt, J.C., Gupta, A. \& Kauffman, R.J. 2008. Making Sense of Technology Trends in the Information Technology Landscape: A Design Science Approach. MIS Quarterly, 32(4), 779-809.

[31] Arthur, W.B. 2009. The Nature of technology: What it is and how it evolves. Penguin group, UK.

[32] Al-Debei, M.M, \& Avison, D. 2010. Developing a unified framework of the business model concept. European Journal of Information Systems, 19(3), 359-376.

[33] Amit, R. \& Zott, C. 2001. Value creation in E-business. Strategic Management Journal, 22(6-7), 493-520. 
[34] Ojala, A. \& Helander, N. 2014. Value Creation and Evolution of a Value Network: A Longitudinal Case Study on a Platform-as-a-Service Provider. 47th Hawaii International Conference on System Sciences, 975-984.

[35] Autio, E., Nambisan, S., Thomas, L.D.W. \& Wright, M. 2017. Digital affordances, spatial affordances, and the genesis of entrepreneurial ecosystems. Strategic Entrepreneurship Journal, 12(1), 72-95.

[36] Eaton, B., Elaluf-Calderwood, S., Sorensen, C. \& Yoo, Y. 2011. Dynamic structures of control and generativity in digital ecosystem service innovation: the cases of the Apple and Google mobile app stores. London School of Economics and Political Science.

[37] Tiwana, A. 2015. "Evolutionary Competition in Platform Ecosystems," Information Systems Research (26:2), pp. 266281.

[38] Allee, V. 2008. Value network analysis and value conversion of tangible and intangible assets. Journal of Intellectual Capital, 9(1), 5-24.

[39] Rayna, T. \& Striukova, L. 2016. The Impact of 3D Printing Technologies on Business Model Innovation. Advances in Intelligent Systems and Computing, 261, 119132.

[40] Morris, M., Schindehutte, M. \& Allen, J. (2005) The entrepreneur's business model: toward a unified perspective. Journal of Business Research, 58(6), 726-735.

[41] Gawer, A. 2009. "Platform dynamics and strategies from product to services," in Platforms, Markets and Innovation, A. Gawer (ed.), UK: Edward Elgar Publishing, pp. 45-76.

[42] Reuver, M., Sørensen, C., and Sasole, R.C. 2017. "The digital platform: a research agenda," Journal of Information Technology.

[43] Bresnahan, T.F. \& Greenstein, S. 1999. Technological competition and the structure of the computer industry. The Journal of Industrial Economics, 47(1), 1-40.

[44] Rysman, M. 2009. The economics of two-sided markets. Journal of Economic Perspectives, 23(3), 125-143.

[45] Boudreau, K.J. \& Hagiu, A. 2009. Platform rules: Multisided platforms as regulators. Platforms, markets and innovation, 163-191.

[46] Rochet, J-C., and Tirole, J. 2003. "Platform Competition in Two-Sided Markets," Journal of the European Economic Association (1:4), pp. 990-1029.

[47] Hyrynsalmi, S., Suominen, A., and Mäntymäki, M. 2016. "The influence of developer multi-homing on competition between software ecosystems," Journal of Systems and Software (111), pp. 119-127.

[48] Schreieck, M., Wiesche, M. \& Krcmar, H. 2016. Design and Governance of Platform Ecosystems-Key Concepts and Issues for Future Research. Proceedings of European Conference on Information Systems (ECIS), Research Paper 76.

[49] Yin, R. K. 2009. Case Study Research: Design and Methods (4th ed.). Sage Publications.

[50] Miles, M. B., Huberman, A. M., \& Saldaña, J. 2014. Qualitative Data Analysis: A Methods Sourcebook. Sage Publications.
[51] Huber, G. P., \& Power, D. J. 1985. Retrospective reports of strategic-level managers: Guidelines for increasing their accuracy. Strategic Management Journal, 6(2), 171-180.

[52] Pettigrew, A. M. 1990. Longitudinal Field Research on Change: Theory and Practice. Organization Science, 1(3), 267-292.

[53] Viswanathan, S. \& Anandalingam, G. 2005. Pricing strategies for information goods. Sadhana, 30(2-3), 257-274.

[54] Ojala, A. 2016. Discovering and creating business opportunities for cloud services. Journal of Systems and Software, 113, 408-417.

[55] Cortimiglia, M. N., Ghezzi, A., \& Renga, F. (2011). Mobile applications and their delivery platforms. IT Professional, 13(5), 51-56.

[56] Diba, V., \& Wagner, C. (2015). Success within app distribution platforms: The contribution of app diversity and app cohesivity. Proceedings of the Annual Hawaii International Conference on System Sciences, 2015-March, $4304-4313$.

[57] Yoo, Y., Henfridsson, O., and Lyytinen, K. 2010. The New Organizing Logic of Digital Innovation: An Agenda for Information Systems Research, Information Systems Research 21(4), 724-735.

[58] Moore, C.L. 2009. Digital Games Distribution: The Presence of the Past and the Future of Obsolescence. M/C Journal, 12(2).

[59] Waelbroeck, P. 2013. Digital Music: Economic Perspectives. SSRN Scholarly Paper. Social Science Research Network.

[60] OECD 2017. Japan Policy Brief. OECD Better Policies Series.

[61] Ojala, A. \& Tyrväinen, P. 2011. Value networks in cloud computing. Journal of Business Strategy 32(6), 40-49. 